Short Communication

\title{
Assembling of NiOx/MWCNTs-GC Anodic Nanocatalyst for Water Electrolysis Applications
}

\author{
Islam M. Al-Akraa*, Yaser M. Asal, Saher D. Khamis \\ Department of Chemical Engineering, Faculty of Engineering, The British University in Egypt, Cairo \\ 11837, Egypt \\ *E-mail: islam.ahmed@bue.edu.eg; islam0886@yahoo.com
}

doi: $10.20964 / 2018.10 .01$

Received: 14 May 2018 / Accepted: 3 June 2018 / Published: 1 September 2018

Glassy carbon (GC) electrode is intended to be modified with nickel oxide (NiOx) and multiwalled carbon nanotubes (MWCNTs) in the anodic reaction of water electrolysis. NiOx deposition time is optimized and a $5 \mathrm{~min}$ was enough to attain the maximum activity. A further modification of the catalyst with MWCNTs could greatly enhance its stability during continuous electrolysis. As an outcome, an energy amount of $21.7 \mathrm{kWh} / \mathrm{KgO}_{2}$ is minimized. Several electrochemical and materials characterization setups will be utilized to test the catalyst activity and to know its geometry and structure.

Keywords: Catalysis; Water splitting; Nickel; MWCNTs.

\section{$\underline{\text { FULL TEXT }}$}

(C) 2018 The Authors. Published by ESG (www.electrochemsci.org). This article is an open access article distributed under the terms and conditions of the Creative Commons Attribution license (http://creativecommons.org/licenses/by/4.0/). 